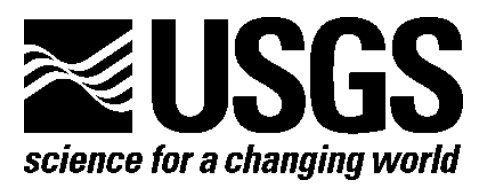

\title{
An Occurrence Model for the National Assessment of Volcanogenic Beryllium Deposits
}

By Nora K. Foley, Robert R. Seal, II, Nadine M. Piatak, and Brianna Hetland

Open-File Report 2010-1195

U.S. Department of the Interior

U.S. Geological Survey 


\section{U.S. Department of the Interior \\ KEN SALAZAR, Secretary}

\section{U.S. Geological Survey \\ Marcia K. McNutt, Director}

U.S. Geological Survey, Reston, Virginia 200x

Revised and reprinted: 2010

For product and ordering information:

World Wide Web: http://www.usgs.gov/pubprod

Telephone: 1-888-ASK-USGS

For more information on the USGS-the Federal source for science about the Earth,

its natural and living resources, natural hazards, and the environment:

World Wide Web: http://www.usgs.gov

Telephone: 1-888-ASK-USGS

Suggested citation:

Foley, N.K., Seal, R.R., II, Piatak, N.M., and Hetland, B.R., 2010, An occurrence model for the national assessment of volcanogenic beryllium deposits: U.S. Geological Survey Open-File Report 2010-1195, 4 p.

Any use of trade, product, or firm names is for descriptive purposes only and does not imply endorsement by the U.S. Government.

Although this report is in the public domain, permission must be secured from the individual copyright owners to reproduce any copyrighted material contained within this report. 


\title{
An Occurrence Model for the National Assessment of
}

\section{Volcanogenic Beryllium Deposits}

\author{
By Nora K. Foley, Robert R. Seal, II, Nadine M. Piatak, and Brianna Hetland
}

The current global and domestic mineral resources of beryllium for industrial uses are dominated by ores produced from volcanogenic epithermal beryllium deposits, which are part of a lucrative subset of the general class of non-pegmatitic beryllium deposits formed by igneous and hydrothermal processes (for example, Barton and Young, 2002). At the present time, beryllium ores produced at the Spor Mountain deposit, Juab County, Utah, constitute the principal global and domestic resource of beryllium for computer, telecommunications, aerospace, defense, and other industrial applications (Jaskula, 2010). The annual worldwide mining production of beryllium (including the United States, Brazil, China, Madagascar, Mozambique, and Portugal) currently is estimated to be 140 metric tons; over 85 percent is from Spor Mountain (Jaskula, 2010).

The general occurrence model summarized here is intended to provide a descriptive basis for the identification and assessment of undiscovered beryllium deposits of a type and style similar to those found at Spor Mountain. The assessment model is restricted in its application in order to provide a coherent basis for assessing the probability of the occurrence of similar economic deposits using the current U.S. Geological Survey methodology (Singer and Berger, 2007). The model is intended to be used to identify tracts of land where volcanogenic epithermal replacement-type beryllium deposits hosted by metaluminous to peraluminous rhyolite are most likely to occur. Only a limited number of deposits or districts of this type are known, and only the ores of the Spor Mountain district have been studied in detail. The model highlights those distinctive aspects and features of volcanogenic epithermal beryllium deposits that pertain to the development of assessment criteria and puts forward a baseline analysis of the geoenvironmental consequences of mining deposits of this type. Significant papers upon which the beryllium deposit assessment model is based include the following: Lindsey and others (1973, 1975), Lindsey (1977, 1979), Burt and Sheridan (1981), Burt and others (1982), Christensen and others (1982, 1984), Ludwig and others (1982), Barton and Young (2002).

Volcanogenic epithermal beryllium deposits can form where the potential exists for the interaction of hydrothermal fluids with volcanic rocks of a lithophile-rich composition that contain a highly reactive lithic component (for example, carbonate clasts). Volcanic and hypabyssal high-silicacontent, biotite-bearing topaz rhyolite and granite porphyry constitute the most well-recognized igneous suites associated with these beryllium deposits. The exemplar setting is an extensional tectonic environment (such as the Basin and Range physiographic province) where younger topaz-bearing igneous rock sequences overlie older dolomite, quartzite, shale, and limestone sequences. The mined deposits and related mineralized rocks at Spor Mountain constitute the only known economic occurrence of volcanogenic epithermal beryllium, having proven reserves of 15,900 metric tons of total 
contained beryllium. The principal commodity produced at mines in the Spor Mountain district is beryllium, and it is chiefly derived from the mineral bertrandite, although beryllium-bearing smectites (saponite) also occur in association with the deposits. The ores at Spor Mountain reportedly average less than 1 percent beryllium oxide and are economically competitive with imported beryl concentrates because they are minable by open-pit methods and can be extracted by acid leaching. At Spor Mountain, tuffaceous breccias and stratified tuffs that contain the beryllium ore formed as a result of explosive iron- and lithophile-rich volcanism that brought carbonate and other lithic fragments to the surface through vent structures that cut the underlying dolomitic Paleozoic sequences. The tuffaceous sediments and lithic clasts make up volcaniclastic surge deposits. Hydrothermal fluids are thought to have leached beryllium and other elements from volcanic glass and redeposited the beryllium as bertrandite upon reaction of the hydrothermal fluid with carbonate in lithic-rich sections of tuff. Hydrothermal alteration of dolomite clasts formed layered nodules of calcite, opal, and fluorite. At Spor Mountain, the principal beryllium ore mineral, bertrandite, occurs as inclusions in fluorite. Distinctive hydrothermal alteration assemblages and elemental enrichments in the tuff and surrounding volcanic rocks include regional diagenetic clays and potassium feldspar; halos of Nb, Ta, F, Sn, Mo, and Li; intense potassium feldspathization; and secondary sericite and lithium-bearing smectite in the immediate vicinity of beryllium ore.

The formation of the beryllium deposits is thought to be due to the coincidence of multiple factors: (1) a source-high-silica-content, lithophile-rich magmas capable of producing the volcanic and hypabyssal high-silica-content biotite-bearing topaz rhyolite and granite porphyry that are included in the igneous source rocks; (2) a driver-a process such as magma mixing where hot mafic magma is injected into colder felsic magma, setting off vigorous convection in the chamber and leading to explosive lithophile-rich volcanism; (3) a site-a host tuff that contains an abundance and distribution of dolomite clasts; the carbonate lithic fragments and glassy features provide the porosity and permeability, as well as the geochemical and mineralogical components, that are necessary to allow the deposits to form; (4) a trap-the confined position of the host tuff between the relatively impermeable Paleozoic rocks and the younger topaz-bearing, rhyolitic lava; and (5) a delivery system-convecting hydrothermal fluids that are enriched in beryllium, iron, and other lithophile elements and are capable of replacing dolomite with calcite, opal, fluorite, and bertrandite.

Other deposit models found in association with the volcanogenic epithermal beryllium deposits include volcanogenic uranium, volcanogenic and replacement fluorspar deposits, and fumerolic gemquality beryl deposits. Topaz-bearing rhyolites, like those associated with the volcanogenic epithermal beryllium deposits, also are of exploration significance for a range of additional rare metal commodities and deposit models, including other volcanogenic deposits; tin, fluorite and silver base-metal districts; tungsten belts; topaz-rich porphyry; and molybdenum-tungsten deposits of the Climax and Henderson type.

The environmental geochemistry of beryllium deposits and their associated mine wastes, including those at Spor Mountain, have been the subject of several studies (Stonehouse 1986; Deubner and others, 2001; Stefaniak and others, 2008). Most of the environmental concerns focus on airborne particles associated with ore and metallurgical processing. Only a limited amount of geoenvironmental information is available for the Spor Mountain deposit. Ores at Spor Mountain are mined by open-pit methods. Because of the low grade of the ore, essentially all of the mined and processed ore becomes waste. Studies of beryllium toxicity have shown that neither beryllium sensitization nor chronic beryllium disease has been diagnosed in miners at Spor Mountain, which is consistent with the low beryllium concentrations in the ore. The key geologic features that may relate directly to the geoenvironmental characteristics include the lithophile-rich, high-silica-content rhyolite hosts, 
associated carbonate rocks, and a sulfide-poor ore assemblage of bertrandite, silica, calcite, fluorite, potassium feldspar, and clays. Collectively, these features contribute to a deposit type for which minimal environmental concerns are present, such that ecosystem issues related to mining are unlikely in the vicinity of the Spor Mountain mine. For example, beryllium concentrations in excess of the drinking water standard (4 micrograms per liter) are unlikely because of the arid climate, lack of surface water, the low concentrations of beryllium and uranium in the ores, and the low solubility of bertrandite.

Rhyolitic magmas rich in fluorine, beryllium, tin, and other lithophile metals are the favorable magmatic source whereas porous carbonate-bearing tuffs and glassy volcaniclastic rocks are the favorable hosts for large disseminated beryllium deposits of this type. Deep fractures, such as margin faults and caldera ring fractures related to extensional tectonics of the Basin and Range province, may be instrumental in tapping the sources of rhyolitic magma and lithophile-rich mineralizing fluids. Magma mixing is thought to provide the primary mechanism for explosive volcanism, and nearby fluorspar and uranium deposits may indicate the presence of lithophile-rich, mineralizing, hydrothermal fluids capable of transporting beryllium. The conversion of dolomite to fluorite results in the release of large quantities of carbonate ions and a subsequent increase in the $\mathrm{pH}$ of the mineralizing solutions, which can be expected to result in widespread and pervasive hydrothermal alteration halos as the more alkaline fluids alter the glass and silicates to smectite, sericite, and potassium feldspar. A favorable indicator mineral is the presence of abundant early lithium-bearing trioctahedral smectite, which forms as magnesium becomes available from dolomite and as lithium is supplied by mineralizing solutions. Anomalous concentrations of trace elements (including fluorine, beryllium, cesium, lithium, gallium, niobium, and yttrium, in combination) in otherwise unaltered volcanic rocks also may indicate proximity to volcanogenic beryllium deposits.

\section{References Cited}

Barton, M.D., and Young, S., 2002, Non-pegmatitic deposits of beryllium: mineralogy, geology, phase equilibria and origin, in Grew, E.S., ed, Beryllium; Mineralogy, petrology and geochemistry: Reviews in Mineralogy and Geochemistry, v. 50, p. 591-691.

Burt, D.M., and Sheridan, M.F., 1981, Model for the formation of uranium/lithophile element deposits in fluorine-rich volcanic rocks, in Goodell, P.C., and Waters, A.C., ,eds., Uranium in volcanic and volcaniclastic rocks: American Association of Petroleum Geologists Studies in Geology 13, p. 99109.

Burt, D.M., Bikun, J.V., and Christiansen, E.H., 1982, Topaz rhyolites; Distribution, origin, and significance for exploration: Economic Geology, v. 77, p. 1818-1836.

Christiansen, E.H., Burt, D.M., and Sheridan, M.F., 1982, The geology and geochemistry of topaz rhyolites from the western United States: Geological Society of America Special Paper 205, 82 p.

Christiansen, E.H., Bikun, J.V., Sheridan, M.F., and Burt, D.M., 1984, Geochemical evolution of topaz rhyolites from the Thomas Range and Spor Mountain, Utah: American Mineralogist, v. 69, p. 223236.

Deubner, D., Kelsh, M., Shum, M., Maier, L., Kent, M., and Lau, E., 2001, Beryllium sensitization, chronic beryllium disease, and exposures at a beryllium mining and extraction facility: Applied Occupational and Environmental Hygiene, v. 16, no. 5, p. 579-592.

Jaskula, B.W., 2010, Beryllium: U.S. Geological Survey, Mineral Commodity Summaries, p. 28-29.

Lindsey, D.A., 1977, Epithermal beryllium deposits in water-laid tuff, western Utah: Economic Geology, v. 72, p. 219-232. 
Lindsey, D.A., 1979, Preliminary report on Tertiary volcanism and uranium mineralization in the Thomas Range and northern Drum Mountains, Juab County, Utah,: U.S. Geological Survey Open-File Report 79-1076, 101 p.

Lindsey, D.A., Ganow, H., and Mountjoy, W., 1973, Hydrothermal alteration associated with beryllium deposits at Spor Mountain, Utah: U.S. Geological Survey Professional Paper 818-A, p. A1-A20.

Lindsey, D.A., Naeser, C.R., and Shawe, D.R., 1975, Age of volcanism and mineralization in the Thomas Range, Keg Mountain, and Desert Mountain, Western Utah: U.S Geological Survey Journal of Research, v. 3, p. 597-604.

Ludwig, K.R., Lindsey, D.A., Zielinski, R.A., Simmons, K.R., 1982, U-Pb ages of uraniferous opals and implications for the history of beryllium, fluorine, and uranium mineralization at Spor Mountain, Utah: Earth and Planetary Science Letters, v. 46, p. 221-232.

Singer, D.A., and Berger, V.I., 2007, Deposit models and their application in mineral resource assessment, in Briskey, J.A., and Schulz, K.J., eds., Proceedings for a Workshop on Deposit Modeling, Mineral Resource Assessment, and Their Role in Sustainable Development: U.S. Geological Survey Circular 1294, 143 p.(Also available at http://pubs.usgs.gov/circ/2007/1294/.) Stefaniak, A.B., Chipera, S.J., Day, G.A., Sabey, P., Dickerson, R.M., Sbarra, D.C., Duling, M.G., Lawrence, R.B., Stanton, M.L., and Scripsick, R.C., 2008, Physicochemical characteristics of aerosol particles generated during the milling of beryllium silicate ores; Implications for risk assessment: Journal of Toxicology and Environmental Health, part A, v. 71, p. 1468-1481.

Stonehouse, J., 1986, Physics and chemistry of beryllium: Journal of Vacuum Science and Technology A, v. 4, no. 3, p. 1163-1170. 